\title{
Globalization and Growth Symptoms of Economic Changes Versus Legal Reforms in Albania and Management Challenges Too
}

\author{
Msc Ledja Kingji ${ }^{1}$ \\ Phd(c) Krenare Vokshi² \\ Prof Dr. Alba Robert Dumi ${ }^{3}$ \\ ${ }^{1}$ Law Department Tirana University, Albania \\ 2SEEU University, Macedonia \\ 3Prof As Dr, Lector in "Ismail Qemali" VIora University Albania \\ Email: alba.besi12@gmail.com
}

Doi:10.5901/mjss.2017.v8n1p457

\begin{abstract}
The last years that there is a significant decline in economic growth, there are real freezing increase in budget revenues, deepening budget deficit, an increase of the stock, the debt stock, deterioration of the trade balance, the decline of crediting to economy, remittances are also in decline, while the EURO and USD continue to rise towards ALL (Albanian Lek). Such indicators are enough symptoms of the concerns why the economic growth in future periods may be difficult and will require more time to return to levels before the crisis. Without high rates of economic growth every economic challenge, social and integration becomes too much difficult in our country. This topic that I am presenting consist in improving the wider usage of strategic management in medium-sized enterprises and small ones ,in our country.
\end{abstract}

Keywords: Legal analyze, Economic growth, Trade balance, Management of SME, Legal reforms.

\section{Introduction}

It seems that the time has fully come to be more clear in the basic objectives of development and growth model for the next 10-20 years. This lack becomes it more severe and the fact that the main political forces are in constant antagonism between them, which is expressed in the negative attitudes of each mutual economic achievement and the neglect shown to the concept of " a national strategy development " prepared with the utmost political and scientific consensus needed and respected by both sides. We are in a crucial moment to make precise concept of a clear policy for economic growth model and its essential factors. Closing It and In front of an indisputable fact. The current guarantee model of economic growth in Albania was based mainly on remittances from the emigration, which in some years have been even higher than 1 billion Euros per year.

Many donations as a poor country and the development that we have benefited as wholesale from soft loans and foreign aid, has really been an important artery that regularly furnished our economy, massive privatizations which have created to our budgets the luxury of being in balance and minimal deficit. Mostly agricultural self-employment, "boom" of 15-year-old construction sector, the dismissal of unemployment towards Greece or Italy, the binding recommendations of the IMF, appears to be moving toward total or partial exhaustion.

Even in18-year policies with absolute priority "maintaining macroeconomic balances", thus creating opportunities for economic growth which does not seem to be a single one. The time has come to do more structural policies, well addressed and wide enough for promoting the maximum economic growth, to ensure the sustainability of its factorial. (R. Aveni, 1995)

For the study of this topic are used the primary researches which are supported by citations of publications, from the managers of big business in the world and secondary researches which include raising hypotheses and development of various publications as well as online searches. During these twenty years, Albania has made an undeniable economic progress. 


\subsection{The goals of this paper research}

1. A better life in the country's economic and social offering employment opportunities and growth income .

2. Harmonious and long-term development of businesses based on the principles of attitude

3. Improvement of financing of local businesses

- Increase the level of crediting and the creation of the Albanian Guarantee Fund of credits.

- Increased funds for microcredit.

- Strengthening the capacity of institutions of Microcredit

4. The objective of strategic management to support the overall goal of developing in Albania.

\subsection{Methodology of this paper research}

What are the best structural policies that the European economy convert us, where we aim to integrate? Which will be sectors that will make 'the motor" of the Albanian economy in the coming years? Tourism? Agriculture and agroindustry? Energy? Industry? Infrastructure? Education? Knowledge economy? Services? The small and medium business development? etc.

\section{Literature Review and Hypotheses}

But at the same time assessment of the debates has led to the conclusion that even after 20 years of transition are inherited many unfinished issues, missed reforms, uncrossed problems, and that's why few questions and dilemmas should get an answered, in front of which is currently the socio-economic development and its opinion.

Hypotheses of this paper research

Some of these issues can be:

$\mathrm{H} 1$. Is there any theoretical context for the issues of economic model we are discussing about?

H 2. Has it completely finished the economic transition of Albania?

$\mathrm{H} 3$. What are the main achievements of this transition, mistakes, failures, dilemmas and challenges of the future?

Which model are we going to select? What vision and perspective for the macroeconomic role stability will we have, about the control over the budget deficit and public debt, in the context of the global crisis and its impact? Does Albanian economy need an absolute restructuring?

The following questions are being analyzed that are taken into consideration during the research

Which will be the priorities of development? How will this model be supported in the use of internal resources and new to our economy and how coherent is this the newest developments of global development, green development, climate change, water management and energy, innovation, technology, education, age of the internet and digitalization?

Is our economy ready to pass from a developing economy to a developed economy, exporting, competing with what comparative disadvantages and integrated in the region and on the continent?

Will the property issues be finally settled and what role will market play in financial ground in this model.

- How will it go on with to the development of regulatory reforms to expand economic freedom and to enhance the role of business and domestic and foreign investment in our economy?

- Will we have a synergy of economic development with employment and social development in the country?

- Will this bring economic development and to improve the quality of population life, in terms of age structure and its territorial development across the country.

- Which will be the role of economic diplomacy and new perspective of cooperation with international financial institutions?

\section{The Significant Indicators of this Paper Research Study}

Every business needs to develop a strategy by offering more competitive in its market. Strategic levels of international businesses have some unique features. To follow this strategy state level in which this arises is the most important mass expansion of its products. This is comprised of four levels.

The levels are: 1-Factors of production refer to all inputs necessary to compete in an industry such as labor, land, natural resources, capital and infrastructure. Of course these are based on a specific industry. If an industry has these factors specialized and advanced, than they can become one of the most successful industries. 
Perscriptive conditions are characterized by a nature and a large proportion of buyers who have a need for their own market share in the industry of goods and services. A significant measure of the market segment can produce a slight degree of efficiency and as much as competitive.

Related and supporting industries is the third dimension in this model. Italy's leading footwear was done because of this dimension.

What are the best structural policies that the European economy converts us, where we aim to integrate? Which will be sectors that will make "the motor" of the Albanian economy in the coming years?

It seems that the time has fully come to be clearer in the basic objectives of development and growth model for the next 10-20 years. This lack becomes it more severe and the fact that the main political forces are in constant antagonism between them, an antagonism which is expressed in the negative attitudes of each mutual economic achievement and the neglect shown to the concept of " a national strategy development " prepared with the utmost political and scientific consensus needed and respected by both sides.

The current guarantee model of economic growth in Albania was based mainly on remittances from the emigration, which in some years have been even higher than 11 milliard Euros per year. Many donations as a poor country and the development that we have benefited as wholesale from soft loans and foreign aid, has really been an important artery that regularly furnished our economy, massive privatizations which have created to our budgets the luxury of being in balance and minimal deficit

Even in18-year policies with absolute priority "maintaining macroeconomic balances" thus creating opportunities for economic growth which does not seem to be a single one. The time has come to do more structural policies, well addressed and wide enough for promoting the maximum economic growth, to ensure the sustainability of its factorial.

This dimension helps companies in obtaining raw materials from the factory.

The structure, firm strategy and rivalry is the fourth dimension, which is the dimension with specific growth industries. The line of this dimension avoids competing firms with a structure or strategy. Earlier the attention was placed on the training of managers and executives study and later these things changed because the technology took advance. Japanese products have facilitated the work of managers under the program. (Harris, T.G 1997)

Strategy to reduce global costs of industries, are usually located in the state where they started their own business. Economy of scale is the main purpose for the operation of various industries in every country of the world. As explanation in a strategic focus some global air companies are thinking to use low cost strategy.

\section{Diversification and Innovation Development Strategy}

International diversification indicates a potential firm, which have to achieve their returns based on innovation. International diversification may be necessary to improve resources. In an environment that has many changes diversification assists with technological changes. Relationship in a global diversification, innovation and resources are interrelated. Many performance levels are needed to prove the innovation and resources required for development.

Researches can improve the profits of a company because of the potential capabilities of diversification with innovation performance or some have argued that the returns are increasing but this diversification has a very big risk. International expansion is very difficult to manage because there are risks. (Kester, F \& Wollenberg, A.L 1986) Chief among them are economic and political risks because due to these risks by diversification of large firms are accustomed to the conditions of a market in competitive situations. The risk policy has to do with a government concentration creating much problem. The economic risk concerns exchange rates and market expansion line.

\section{Types of Competitive Strategy}

Strategic alliances are partnerships between firms and their sources of competition foundation skills are combined for the development and distribution of goods and services. Joint ventures are when two or more firms establish an independent company together and share the profit equally.

Strategic business alliances are consisting on partnership that have a different percentage on the surface but are equal among them. Unequal strategic alliances are formed by companies and customers agreement procedures or Distribution, in order to distribute goods and services. Types of competitive strategies at the business level are complementary alliances, alliances and reducing competition, the alliance responsible for reducing competition and alliance strategy. While the types of competitive strategy at the corporate level are diversifying alliances and franchises (Dumi A. SME strategy 2015) 


\section{Innovation}

Technological revolution and greater competition in international markets have increased the importance of competitive innovation. Returns have shown that firms competing in the global industry and invest more in innovation to increase their profits. (Harris, T.G 1993)

In fact, investors often react positively to new products and enhance the firm's stocks pegged to steer cooperation level as better one. Corporate enterprises include firm commitments and actions, that decide to develop and manage innovation. (Kester, F \& Wollenberg, A.L 1986)

Formally undertaken Corporate is a set of skills to produce goods and services effectively and to have a successful commercialization. Strategic leaders, managers and entrepreneurs all have an important role and are crucial to a corporation effective one. Innovation is an act of creation or development of a new product. Innovation is a process for creating a commercial product from similar firms. Simulation usually leads to products or processes standardization in America the most critical of all activities has been innovation. (Dumi A. SME strategy, 2015)

Many firms are able to generate ideas that lead to the commercialization but these goals have difficulties in innovation. Leaders and their words contain inspired symbolic value to the organization. Their work is very important for product ideas and to support the special needs of the product cycle. Entrepreneurs are the people who are the first to watch and analyze the economic opportunities that will emerge in the economic environment. (Gillespie, H.R 1980)

By joining the two processes entrepreneurship is an activity that is used to create goals in a single organization. J. B. Barney, 1994. The autonomous strategic behavior is a process that every product is combined with product ideas. Often through political processes, they develop and coordinate the commercial goods and services successfully. This attitude finds support in commercial centers.

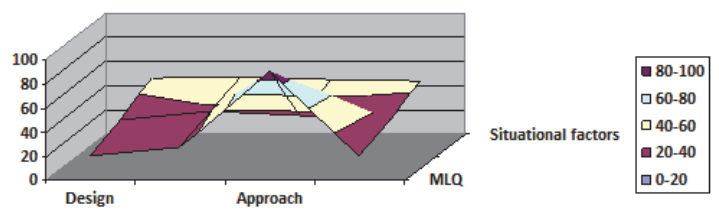

Tab 1. Long term characterized and short term perspectives

Source: Dumi A, MJSS, Nr 32012

\section{Findings}

This study empirically examines the impact of debt management policies on borrowing costs incurred by state governments when issuing debt in the municipal bond market. Strategy induced behavior (Fiedler, F.E 1967)

Strategy induced behavior is a process through which a current strategy is innovation of strategy product. In this situation the country is being filtered by the structure of the product. Development and implementation of the corporate strategy is generally complicated. A company must have always intended to fulfill its purpose. Creation and commercialization of goods and services is a difficult process.( Harris, T.G 1993)

Design and technology transfer by infrastructure engineers which always seeks the opportunity and the right time. Stage design requires a high degree of integrity to the process of innovation function. Operating importance of integrity has been recognized for a period of time but has never been practiced in the industry until recently. Horizontal organization refers to changes in organizational process where functional management unites the parts to build a hierarchy. Appearances suggest that the key benefit is a horizontal organization that can be even more effective. (Dumi A. SME strategy 2015)

Based on positive political theory and the benefit principle of taxation, it is proposed that states that adhere to best practice debt management policies transmit signals to the credit ratings, investment community and taxpayers that the government should meet its obligations in a timely manner, resulting in lower debt costs. 1 . The donors concurred with this assessment. IDA, starting with the 1998 CAS, considered governance and institution building as one of the central planks of its intervention and identified the need to adopt and implement reforms to build an accountable and transparent state as the most important challenge facing the Government of Albania.

${ }_{1}^{1}$ Donors and government investments, IDA, report 2013 


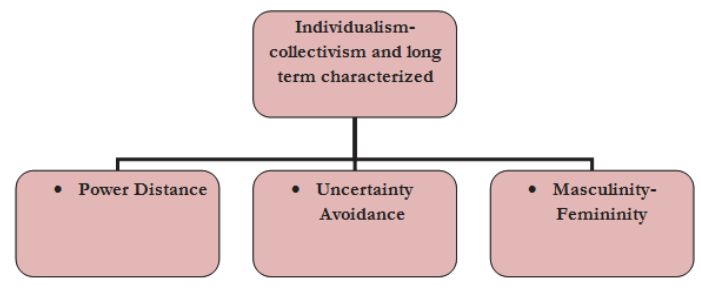

Tab 2. Indicators of growth and short term characterized and short term perspectives

Source: Dumi A, MJSS, Nr 32012

Long-term orientation is characterized by a long-range perspective coupled with a concern for thrift and weak expectations for quick returns on investments (Pacific Rim countries).

Short-term orientation is characterized by a long-range perspective coupled with a concern for thrift and weak expectations for quick returns on investments (Pacific Rim countries). (Gillespie, H.R 1980)

Tab 3: SWOT analysis by powers, weaknesses, opportunities and threats for the study of internal and external context were identified four strategies

\begin{tabular}{|c|c|c|}
\hline Opportunity: & Strategies: & Strategies: \\
\hline $\begin{array}{l}\text { 1. The increase of Internet users market } \\
\text { 2. The increase of sustained prosperity } \\
\text { 3.Fulfillments of legal and political vacuum } \\
\text { 4. Demographic structure (domination by young } \\
\text { people) }\end{array}$ & $\begin{array}{l}\text { 1.The entry strategy and market } \\
\text { growth }\end{array}$ & $\begin{array}{l}\text { 1. The strategy of strategic alliances. (To } \\
\text { provide the necessary funds and organization of } \\
\text { marketing campaigns for the presentation of } \\
\text { products and services to be offered on the } \\
\text { market) }\end{array}$ \\
\hline $\begin{array}{l}\text { Threats: } \\
\text { 1. The rapid technological changes } \\
\text { 2.Adaptation with the new technological } \\
\text { changes }\end{array}$ & $\begin{array}{l}\text { 3.Outsourcing strategy (some } \\
\text { services) } \\
\text { The entry new strategy and low } \\
\text { market growth } \\
\text { The entry strategy and imputed } \\
\text { The entry strategy and market growth } \\
\text { for essential product and services. }\end{array}$ & $\begin{array}{l}\text { 4. Strategy and strategic alliances of } \\
\text { "outsourcing" } \\
\text { (Some services) }\end{array}$ \\
\hline
\end{tabular}

\section{Conclusions and Recommendations}

Integration barriers can kill efforts to integrate effectively the functions of an organization. Departmental functions have been found differences through four dimensions: time orientation, personal orientation, goal orientation and formal structure. Where a person, who has a profession marketer, may have an important function in the product, characteristics and needs of the client gratification (Fiedler, F.E 1967)

These types of features can be violated or may change. Also these different orientations can create barriers through communication functions. Therefore eliminating the barriers, that may do more harm than good to the organization. Another obstacle may be the organizational policies. We can also find many methods and opportunities to improve the organization.

Global competition is a very important element to make a strong business, as a very important aspect, is the formulation of organizations mission and finding appropriate methods for achieving the goal.

But stakeholders are one of those elements that are affected and affect the progress of the organization. Organizations also have their premises which are: external environment analysis or PESTEL consisting of economic factors, social factors political and technological factors. And industrial environment is very important for organizations that environment consists of reformatories entrants, competitive rivalry, buyer powers, etc. (Dumi A. SME strategy 2015)

\section{References}

Falbe, C.M \& Yukl, G. Consequences for managers of using single influence tactics and combinations of tactics. Academy of Management Journal, 1992, 35(3), 638-652. 
Fiedler, F.E. a theory of leadership effectiveness. New York: McGraw-Hill, 1967.

Gillespie, H.R. An investigation of current management/leadership styles of manufacturing executives in American industry. Dissertation Abstracts International, 1980, 41(7a), 3177.

Harris, T.G. the post-capitalist executive: an interview with Peter F.Drucker. Harvard business review, 1993, 71, 114-122.

Hart, S.L \& Quinn, R.E. Roles executives play: CEOs, behavioral complexity, and firm performance. Human Relations, 1993, 46(5), 543574.

Hersey, P \& Blanchart, K.H. Management of organizational behavior: utilizing human resource (4th, ed). Englewood Cliffs, NJ: PrenticeHall, 1982.

Hooijberg, R...,\& Quinn, R.E. Behavioral complexity and the development of effective managers. In R.L. Phillips and J.G.Hunt (eds), strategic management: A multi organizational -levels perspective. New York: Quorum, 1992.

House, R.J. A path-goal theory of leader effectiveness. Administrative Science Quarterly, 1971, 16, 321-338.

House, R.J \& Mitchell, T.R. Path -goal theory of leadership. Contemporary Business, 1974, 3(Fall), 81-98.

Howell, J.M \& Higgins, C.A. Champions of technology. Administrative Science Quarterly, 1990, 35, 317-341.

Joreskog, K.G \& Sorbom, D. Liserel 7: User's reference guide. Mooresville, IN: Scientific Software, 1989.

Kanter, R.M. the new managerial work. Harvard Business Review, 1989 (November-December).

Katz, D.A \& Zaccaro, S.J. An estimate of variance due to traits in leadership. Journal of Applied Psychology, 1983, 68(4), 678-685.

Kester, F \& Wollenberg, A.L. van den. Modulair system methodenleer Quasi experimenteel design. Vakgroep Mathematische Psychologie, Psychologisch Laboratorium, Nijmegen, 1986.

Kipnis, D \& Schmidt, S.Upward influence styles: Relationship with performance evolution, salary, and stress. Administrative Science Quarterly, 1988, 33, 528-402.

Kotter, J.P. the general managers. New York: Free Press, 1982.

Lieberman, S. the effects of changes in roles on the attitudes of role occupants. Human Relations, 1956, 9, 385-402.

Luthans, F \& Lockwood, D.L. Toward an observation system for measuring leader behavior in natural settings. In J.G. Hunt, D. Hosking, C.A> Schriesheim, and R.Steward (eds), Leaders and managers: international perspectives on managerial behavior and leadership. New York : Pergamon Press, 1984.

Mintzberg, H. The nature of managerial work. New York: Harper and row, 1973

Morse, J.J \& Wagner, F.R. Measuring the process of managerial effectiveness. Academy of Management Journal, 1978, 21, 23-35.

Park, R.E. behind our masks. Survey, 1926, 56, 135-139.

Pinder, C, Pinto, P.R \& England, G.W. Behavioral Style and Personal Characteristics of Managers. Technical report, University of Minnesota, Center for the study of organizational performance and human effectiveness, Mineapolis, 1973.

Yukl, G.A. A New Taxonomy for Intergrating Diverse Perspectives On Managerial Behavior. Paper presented at the American Psychological Association meeting, New York, 1987.

Yukl, G.A. leadership in organization. Englewood Cliffs, NJ: Prentice-Hall, 1989. (a) 